\title{
Mixed Municipal Solid Waste Hygienisation for Refuse-Derived Fuel Production by Ozonation in the Novel Configuration Using Fluidized Bed and Horizontal Reactor
}

\author{
Katarzyna Wolny-Koładka ${ }^{1}$ - Witold Żukowski ${ }^{2}$ [D
}

Received: 14 April 2017 / Accepted: 19 September 2017 / Published online: 23 September 2017

(C) The Author(s) 2017. This article is an open access publication

\begin{abstract}
Purpose This study aimed to determine whether mixed municipal solid waste used for alternative fuel production can be effectively treated with ozone hygienisation in a gaseous phase.

Methods It was determined that the use of a fluidised bed reactor and a horizontal reactor with respect to processing the light fraction and the heavy fraction of waste effectively contributes to the elimination or reduction of the number of selected groups of microorganisms inhabiting mixed municipal solid waste. With the use of microbiological analysis, the presence of vegetative bacteria, spores, fungi, actinomycetes and pathogenic bacteria, i.g. Staphylococcus spp., Escherichia coli, Salmonella spp., Shigella spp., Enterococcus faecalis, and Clostridium perfringens were determined.

Results It was found that ozonation contributed to the elimination of the microorganisms in the tested raw materials in different ways. The efficiency of hygienisation was dependent upon whether the process was performed upon the heavy fraction or the light fraction of waste. In addition, the elimination of microorganisms was influenced by drying the samples-this caused a significant decline in their levels of humidity.
\end{abstract}

Katarzyna Wolny-Koładka

katarzyna.wolny@urk.edu.pl

Witold Żukowski

witold.zukowski@pk.edu.pl

1 Department of Microbiology, University of Agriculture in Cracow, Mickiewicza Ave 24/28, 30-059 Cracow, Poland

2 Department of Chemical Engineering and Technology, Cracow University of Technology, Warszawska 24, 31-155 Cracow, Poland
Conclusions Based on the results, it must be considered that presented disinfection process may be used for the hygienisation of raw materials for the production of alternative fuel in the future, given that the source of this fuel can be either a light fraction or a heavy fraction of mixed municipal solid waste.

Keywords Waste hygienisation - Ozone - Fluidized bed · Horizontal reactor $\cdot$ Alternative fuel $\cdot$ Microorganisms

\section{Introduction}

Ozone is a well-known and highly effective disinfectant which destroys bacteria faster than chlorine [1-6]. External cell structures are destroyed as a result of the bacteria making contact with ozone. It then reacts with unsaturated fatty acids contained in the lipids of the cell membrane, causing the oxidation and dissociation of these unsaturated fatty acids. As a result, an outflow of intracellular components to the outside environment and the lysis of microbial cells occur. Subsequently, the internal components of bacterial cells are destroyed. As a consequence of ozone diffusion into the interior of a bacterial cell, reactions with the components including purine and pyrimidine nucleotide building blocks take place. The amino acids which comprise the structural and enzymatic proteins are also affected $[4,5]$.

Ozone's very strong oxidising capacity makes vulnerable to it both gram-positive bacteria (e.g. Listeria monocytogenes, Staphylococcus aureus, Enterococcus faecalis) and Gram-negative bacteria (e.g. Yersinia enterocolitica, Pseudomonas aeruginosa, Salmonella typhimurium, Escherichia coli) vulnerable to it-also vulnerable are viruses, fungi and yeasts (e.g. Fusarium oxysporum, Candida parapsilosis, Candida tropicalis), as well as spores (e.g. Bacillus cereus) 
$[3,4,7]$. According to Pascual et al. [8], the bacteria are more sensitive to ozone than yeast or fungi. Furthermore, Gram-positive bacteria are more sensitive to ozone than Gram-negative and spores are less sensitive than vegetative cells [8].

Ozone, because of its lethal effect, was not only found to be an antibacterial [1,2] and antifungal [9] agent, it also facilitates the removal of pesticides and toxic chemicals [10] and eliminates cereal grain pests during storage [11]. Knowledge of ozone disinfection is quite common, but there are very few examples of its application in the elimination of microorganisms from raw materials used for the production of refuse-derived fuel [RDF] [3-6]. Of these limited examples, one of the most notable is the solution presented by S.R.F. Energy (Rivoire S.P.A via Durini, 7, I-20 122, Italy). The use of ozone as a disinfectant proposed by the company is described in the patent application published on 23.08.2007 [12]. The essence of this solution is to remove the need for increased temperature or disinfection in the liquid phase through use of a solution containing biocidal ingredients which can potentially contain chlorine-based compounds such as calcium hypochlorite, sodium hypochlorite or chlorine dioxide [13-16].
The above-mentioned solution made it possible to avoid RDF moisture increase and higher chlorine content in the product of the disinfection process-this is particularly important in the context of avoiding dioxin emissions during the incineration of RDF [17-21].

The most important components of the solution are the use of: (1) a disinfection chamber into which RDF is introduced; (2) an ozone generator. According to the cited solutions, placing ozone in contact with solids causes: a reduction of the bacterial content to below the level which is considered to be dangerous; the prevention of the rapid growth of microorganisms in the time between RDF production and the disposal of refuse-derived fuel; the elimination of unpleasant odour.

In the illustrated example, $\mathrm{O}_{3}$ is generated with pure oxygen in a corona discharge generator (Fig. 1). As described in the patent, the alternative fuel is in the form of flakes and is fed into the top of the vertical column. Contact with a gaseous medium flowing from below occurs in a countercurrent flow. As described herein, disinfection was not tested in a fluidised bed reactor.

The number of microorganisms was reduced during the application of both the oxygen and the $\mathrm{O}_{2} / \mathrm{O}_{3}$ mixture. In

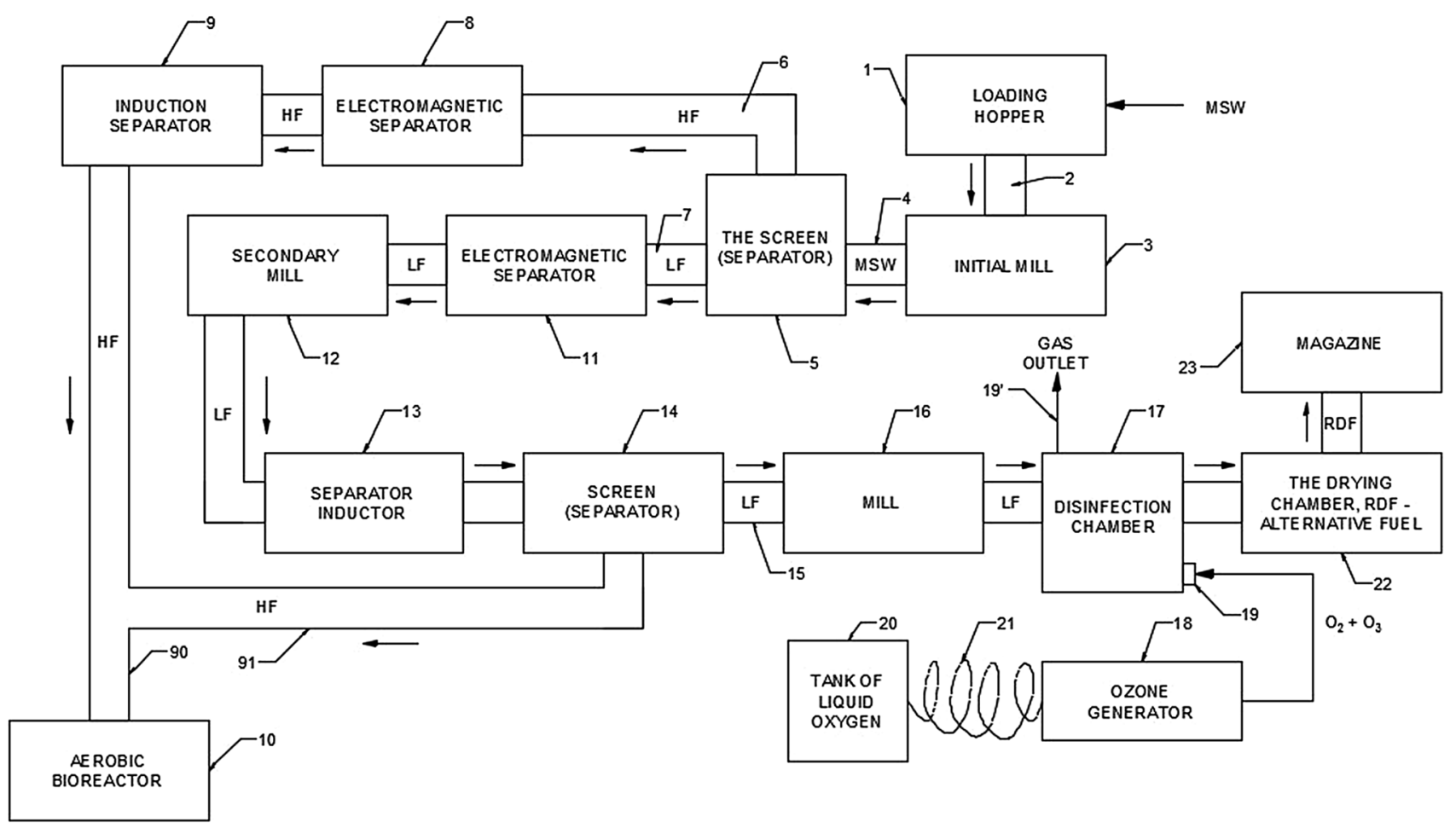

Fig. 1 Diagram of the process for the preparation of alternative fuel with disinfection using oxygen and ozone, based on Coggiola et al. [12]. 1-loading hopper; 2-transporter of raw materials; 3 -initial mill; 4-transporter; 5-the screen (separator); 6-transporter; 7transporter; 8-electromagnetic separator; 9-induction separator; 10-aerobic bioreactor; 11 - electromagnetic separator; 12-second- ary mill; 13-separator inductor; 14-screen (separator) 15-conveyor; 16-mill; 17-disinfection chamber; 18-ozone generator; 19-inlet gas; 19' — gas outlet; 20 — tank of liquid oxygen; 21 -line transfer; 22-the drying chamber; 23 -magazine. $H F$ heavy fraction; $L F$ light fraction; $R D F$ refuse-derived fuel 
the latter case, a decrease in the growth rate of microorganisms also took place for up to $72 \mathrm{~h}$ after the operation. The amount of ozone per $1 \mathrm{~kg}$ of the material ranged from 0.1 to $4.0 \mathrm{~g}$. The contact time varied from 1 to $60 \mathrm{~min}$. The disinfection reactor housed 1 tonne of RDF. At the end of the disinfection process, RDF humidity was $25-45 \%$, and therefore, was directed to a drying chamber where it reached a final humidity of $15 \%$.

A disadvantage of the presented solution is the use of pure oxygen and placing it in contact with combustible material; furthermore, the solution is limited only to the light fraction-the heavy fraction cannot be used to produce RDF.

Municipal solid waste (MSW) is also stabilised and hygienised through biological drying - this is an auto-thermal (self-heating) process utilising the heat released during organic decomposition. Waste heats itself due to the degradation of organic matter involving microorganisms. Biodrying leads to the loss of moisture while preserving (or increasing) the caloric content. As a result, a stable, solid fuel is formed [22]. Another method used for the hygienisation of waste is stabilisation through the use of oxygen. This type of stabilisation consists of the delivery of oxygen to waste placed in special bioreactors or to waste formed into aerated prisms. The use of oxygen is an indispensable part of the process and is needed for the development of wastedwelling microorganisms. Increased microbial activity leads to an increase in heat generated as a result of the processing of organic matter contained in the waste. An increase in temperature to above $60-65{ }^{\circ} \mathrm{C}$, which lasts for several hours, contributes to the hygienisation of waste and continues to stabilise for several days [23]. Another method used in hygienisation is waste liming - this is achieved through the addition of $\mathrm{CaO}$. This treatment aims to reduce the moisture content of the waste while increasing its temperature combined with the change of $\mathrm{pH}$ to a very high level. The above action contributes to the elimination of pathogenic microorganisms and eggs of parasites [24-26]. At present, the use of plasma technology for waste disposal and waste gas disposal appears to be a hopeful option. Therefore, for several years, attempts have been made to use high temperature plasma for the hygienisation of waste [27]. Plasma sterilisation properties are mainly due to the fact that reactive forms of oxygen and nitrogen (i.e. hydrogen peroxide and radicals $\mathrm{OH}, \mathrm{OH}_{2}, \mathrm{NO}, \mathrm{O}_{3}$ ) have a very strong anti-microbial effect. An additional factor that acts on microorganisms is the UV radiation produced during the generation of plasma-this also contributes to the inactivation of microbes [28].

It should be taken into account that before being used as a source of energy, RDF can be stored for a prolonged period of time and may also be subject to various operations, such as pelletisation or transportation-in such cases, there is a potential risk of microbial contamination which should be minimised.
Both light and heavy fractions of MSW, because of the considerable content of organic carbon, may not be stored but must be processed, which leads to organic carbon utilisation, which be achieved either by mechanical-biological treatment (MBT), by incineration [29, 30] or gasification [31, 32]. Prior to this disposal, these fractions may be subject to operations such as transportation, cutting, grinding, pelletisation, where their contact with the environment can present microbiological hazards. Therefore, hygiene of both fractions is an important consideration during these operations.

The aim of this paper is to discuss one method of minimising the biological hazards in an optimised manner using fluidisation and ozone that is obtained without the need to use pure oxygen as a substrate for its production. An additional aim is to develop a method that could be applied to both light and heavy fractions of MSW. Therefore, the paper presents an examination of the process using an ozone generator fed with air instead of pure oxygen. The resulting ozone concentrations are lower than in the case of the application of pure oxygen; however, the fire hazards and the technical complexity are reduced and the cost of the process is lowered.

Studies were designed to evaluate the suitability of the ozonation process as a technique for the hygienisation of waste, both with respect to the light fraction (LF) and the heavy fraction (HF), both originating from municipal waste, to increase the total production of RDF. For this purpose, two different methods of contacting the solid with a gas stream containing $\mathrm{O}_{3}$ were proposed. The effectiveness of the process with regard to the reduction or elimination of microorganisms colonising the raw materials used for the production of alternative fuel was determined.

\section{Materials and Methods}

\section{Materials}

The solid residues studied here come from MSW processing facility (Miki Recykling sp. z o.o., Cracow, Poland) where are they used to RDF production [33]. Both light fraction and heavy fraction were collected in January 2016.

\section{Microbiological Media}

In the analysis were used various media: agar MPA-Malt Peptone Agar (BTL, Poland) for general vegetative bacteria and spores; agar MEA-Malt Extract Agar (BTL, Poland) for mould fungi; Pochon agar (BTL, Poland) for actinomycetes; Chapman agar (BTL, Poland) for Staphylococcus spp.; TBX agar-Tryptone Bile X-glucuronide agar (BTL, Poland) for E. coli; agar SS-Salmonella Shigella 
agar (BTL, Poland) for Salmonella spp. and Shigella spp.; agar SB - Slanetz Bartley agar (BTL, Poland) for Enterococcus faecalis; agar SC-Sulphate and Cycloserine agar (BTL, Poland) for Clostridium perfringens.

\section{Ozonation Process}

Prior to hygiene tests using ozone, a preliminary visual evaluation of the materials was conducted. The size of the samples subjected to the hygienisation operations was selected so that each sample contained a variety of materials in terms of morphology, particle size and type of material that was part of the fraction. Attempts were made to ensure that this diversity was preserved for all samples selected for testing. While maintaining the appropriate size and diversity of each sample, the impact of hygienisation process conditions was assessed and the observed trends were used to attempt to draw conclusions about the effects of these process conditions with regard to inhibiting microbial life.

The tests were performed using samples of raw materials used for the production of alternative fuel. Light fractions (LF) and heavy fractions (HF) of waste (Figs. 2, 3) were analysed-there was a total of 23 samples.

A laboratory stand for disinfection was built using a tubular reactor with a length of $500 \mathrm{~mm}$ and a diameter of $100 \mathrm{~mm}$. The reactor was empty inside and had a mesh with apertures of approx. $2 \mathrm{~mm}$ which was supported on a grid at one end of the reactor. The reactor and the grid were made of polyvinyl chloride (PVC), the mesh was made of polyamide. The reactor was connected to the ozone generator by a flexible hose. The flexible connection was intended to enable the operation of the reactor in both vertical and horizontal configurations.

A commercial device designed for disinfecting rooms, produced by Crown Laboratory R\&D, Poland, was used as

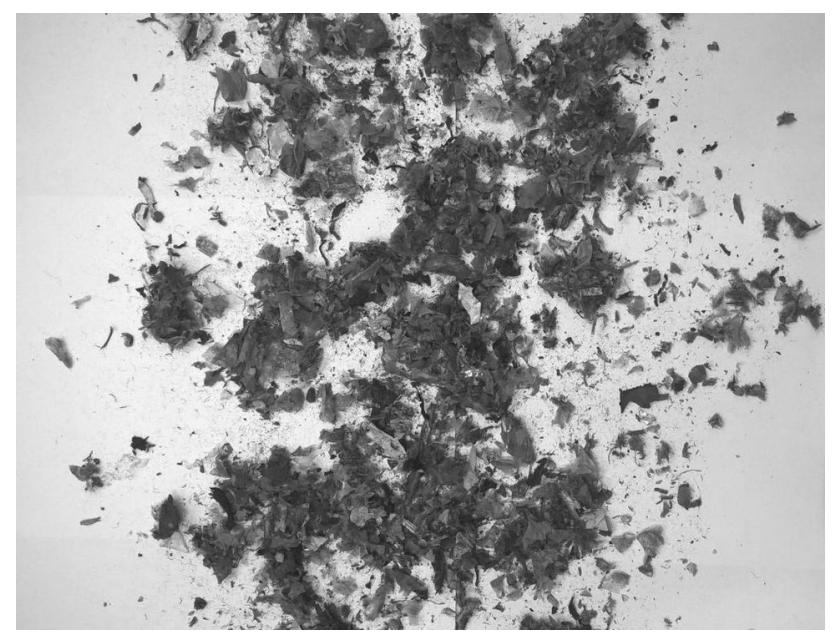

Fig. 2 Light fraction (LF)

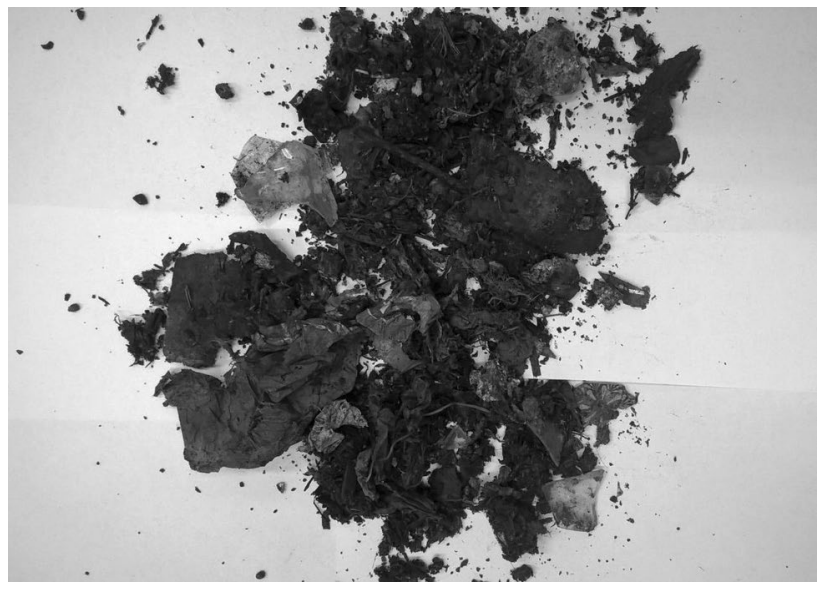

Fig. 3 Heavy fraction (HF)

the ozone generator. This device generates air containing $\mathrm{O}_{3}$ at a flow rate of $220 \mathrm{~m}^{3} / \mathrm{h}$, and ozone yield of $\sim 1.0 \mathrm{~g} / \mathrm{h}$ (ozone concentration measurements were taken at the outlet of the apparatus by FTIR technique using the Gasmet DX4000 analyzer). According to the proposed industry solution presented above, it was found that 1 tonne of material required from 0.1 to $4.0 \mathrm{~kg}$ of $\mathrm{O}_{3}$ (the optimal being $2 \mathrm{~kg}$ ). Using this optimum quantity of $2.0 \mathrm{~kg}$ of $\mathrm{O}_{3}$ as a guideline, it was calculated that $50 \mathrm{~g}$ of solid material (planned sample size) would require $100 \mathrm{mg}$ of ozone - the device would generate this quantity within 6 min. Experiments were planned to last from 15 to $90 \mathrm{~min}$, with sufficient excess time to take into account the partial decomposition of the ozone in the reactor. Configuration of the vertical reactor was designed to work with the light fraction (Fig. 4).

In this configuration, the grid was at the bottom of the reactor and it enabled the loading of a portion $(50 \mathrm{~g})$ of the material tested (light fraction, LF). In this case, the material

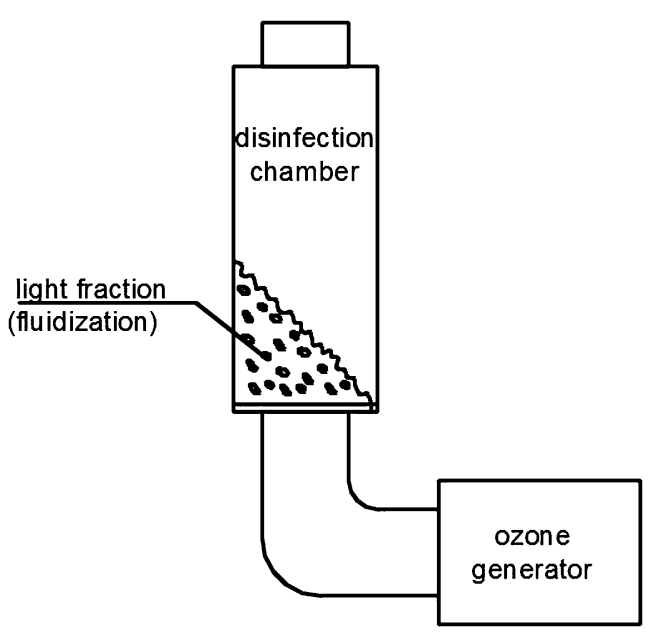

Fig. 4 Fluidised bed of reactor for disinfection of the light fraction 
settled on the bottom of the reactor through which the gas was fed from the ozone generator. The diameter of the reactor was chosen in such a way that most of the particles of the material inside the tube were in a constant state of movement (in the state of fluidisation). This configuration prohibited the blocking the bottom of the reactor by solids and the formation of dead zones in the reactor in which contact between the gas and the solid particles did not occur or was very difficult. No formation of channelling, the continuous and good mixing of solids with the gaseous medium, and equalisation of the temperature of the gas and solid material were other advantages.

The system described above was not adequate for the heavy fraction (HF) which was characterised by very wide variations in particle morphology. In this case, part of the material, i.e. the largest and heaviest components rapidly formed an immobile phase on the bottom of the reactor. This layer completely covered the gas distributor and blocked the gas flow or block distributor only partly, allowing the gas flow and creating a gas passage. In both situations, there was lack of good contact with most of the material and the ozone disinfection did not occur in a proper manner. This behaviour of the material was confirmed by the tests. For HF disinfection, an alternative solution with a horizontal configuration was developed (Fig. 5).

In the horizontal configuration, the granular material occupied a portion of the lateral surface of the reactor and carrier gas containing the ozone flowed over its surface. To intensify the contact of the reactants and thereby facilitate the performance of the reactor, it was vigorously stirred at 5 min intervals so that the solid particles were changing positions during the process.

Test samples were prepared from raw and dried LF and HF. Drying of the samples was carried out at $55^{\circ} \mathrm{C}$ for $48 \mathrm{~h}$ in a drying oven with forced internal air circulation. The variables included in the study were: the type of fraction; the time of contact with ozone; the humidity of the samples (Table 1). The first series of disinfection was carried out for
LF using the non-dried material and for contact times with ozone of 15,30 and $45 \mathrm{~min}$, using the reactor's vertical configuration. The second series of disinfection was carried out for HF in the same manner as for the light fraction, except that the reactor was used in a horizontal configuration. The third series of disinfection was carried out for LF using the material dried for $48 \mathrm{~h}$ and for 90 min of contact time with ozone, using the vertical reactor configuration. The fourth series of disinfection was carried out for dried HF, wherein the contact time with ozone was extended to $120 \mathrm{~min}$ and using the horizontal reactor configuration. Each test was repeated ( $\mathrm{A}$ and $\mathrm{B}$ designation in results section). After the process, the samples (also untreated reference samples) were transferred to sterile string bags and immediately transported to the microbiological laboratory in order to perform further analysis.

\section{Microbiological Analysis}

All samples which were subjected to the process of ozonation were subjected to microbiological analysis as were the reference samples. From each sample, $10 \mathrm{~g}$ of test material was weighed out in order to perform the isolation of microorganisms. Isolation was performed through a series of dilutions using the Koch method with different types of microbiological media. The following groups of microorganisms were identified: general vegetative bacteria and spores (cultured at $37^{\circ} \mathrm{C}$ for $24 \mathrm{~h}$ ); mould fungi (cultured at $28^{\circ} \mathrm{C}$ for 5 days); actinomycetes (cultured at $28{ }^{\circ} \mathrm{C}$ for 7 days). The number of vegetative bacteria and spores testifies to the abundance of nutrients which are readily available to the microorganisms in the raw materials. The variety of bacteria, fungi and actinomycetes also indicates favourable conditions (temperature, substrate $\mathrm{pH}$, humidity) for the growth and development of microorganisms. The presence of the following potentially pathogenic bacteria were also investigated: Staphylococcus spp. (cultured at $37{ }^{\circ} \mathrm{C}$ for $24 \mathrm{~h}$ ); E. coli (cultured at $44{ }^{\circ} \mathrm{C}$ for $24 \mathrm{~h}$ ); Salmonella spp. and
Fig. 5 Horizontal reactor for the disinfection of the heavy fraction

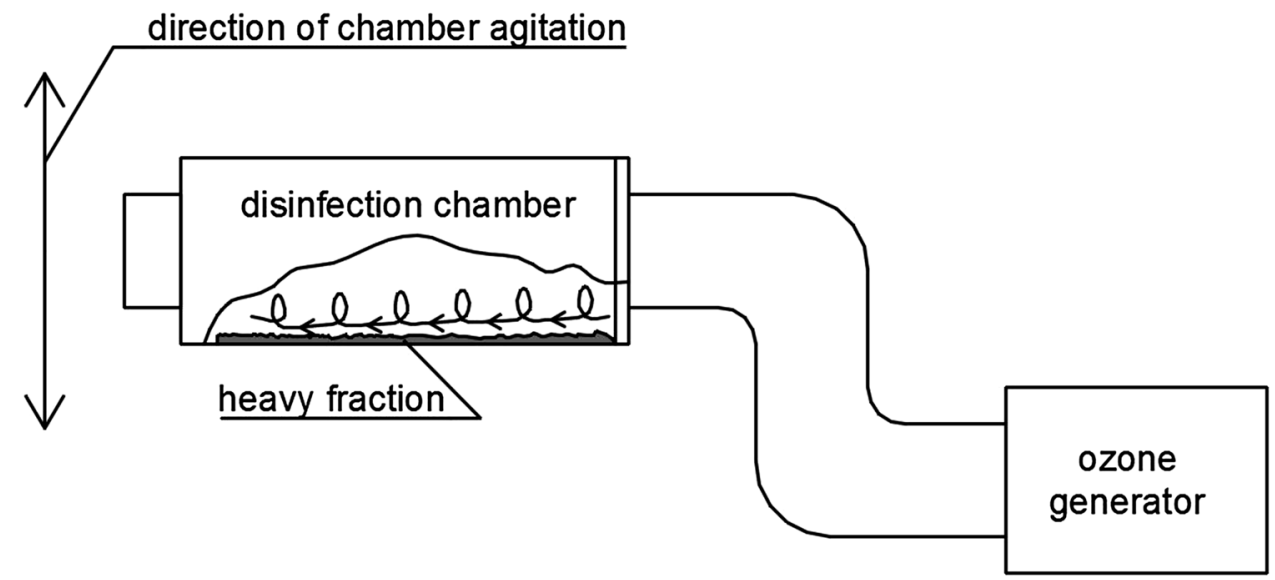




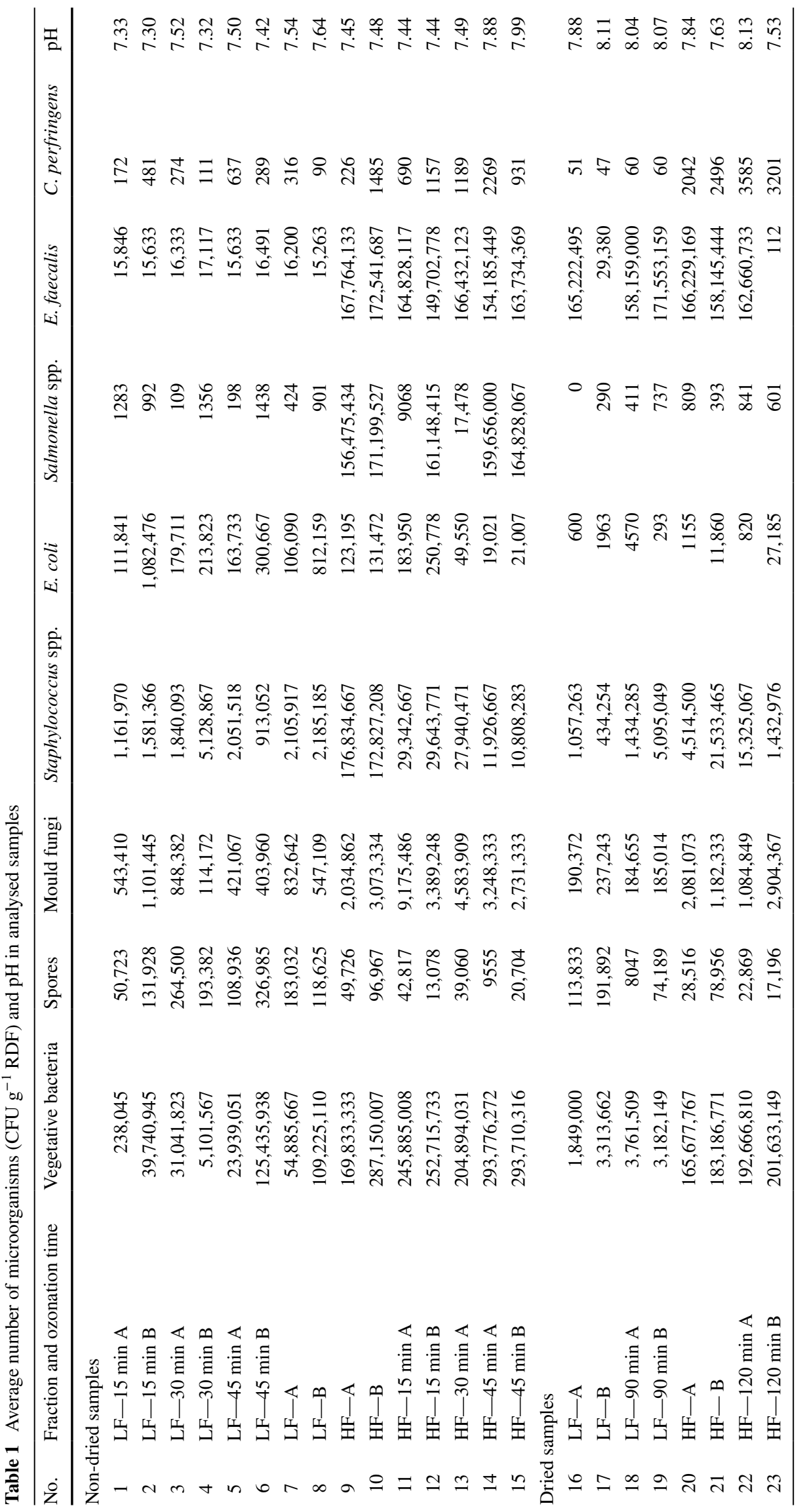


Shigella spp. (cultured at $37^{\circ} \mathrm{C}$ for $24 \mathrm{~h}$ ); Enterococcus faecalis (cultured at $37^{\circ} \mathrm{C}$ for $48 \mathrm{~h}$ ); Clostridium perfringens (cultured at $37{ }^{\circ} \mathrm{C}$ for $24 \mathrm{~h}$ ). The presence of pathogenic bacteria (Staphylococcus spp., E. coli, Salmonella spp., E. faecalis, $C$. perfringens) that may constitute a threat from an epidemiological point of view is an important indicator of microbiological contamination.

The analysis of serial dilutions was performed in triplicate. The number of colony forming units (CFU) of microorganisms was determined by plating dilutions and converting the result per gram of tested material. Preliminary identification of microorganisms isolated from the samples was based on Gram-stained bacteriological preparations and supravital Lugol's solution-stained preparations. Statistical analysis of the results was performed using Statistica v. 12.5 (StatSoft). The mean number of microorganisms in the test samples were calculated, an analysis of variance (ANOVA) was also performed to test the significance of the diversity of results for selected groups of microorganisms subjected to different variants of the ozonation process.

\section{Results and Discussion}

A large population of microorganisms, including pathogenic microorganisms (Staphylococcus spp., E. coli, Salmonella spp., E. faecalis, C. perfringens) was found in the analysed samples. The tested materials were characterised by high microbial biodiversity, including the presence of pathogenic organisms, which could constitute a threat from an epidemiological point of view. The $\mathrm{pH}$ of the analysed samples varied between 7.3 and 8.13, it can therefore be considered that the $\mathrm{pH}$ of the raw materials for the production of alternative fuel did not affect the number of microorganisms (Table 1). Results for the Shigella spp. and actinomycetes are not presented because these microorganisms were not detected in any of the samples analysed.

For HF, more vegetative bacteria were observed than for LF. Drying clearly eliminated vegetative bacteria from the LF while in the case of the HF, changes were minor. Ozone treatment has a weak effect in the case of the HF-the greatest effect is observed for the non-dried LF (Table 1).

In the case of spores, data is significantly different when comparing the results of series A and B. This means that the spores are very unevenly distributed in the tested material, making it very difficult to observe the impact of process conditions on the number of bacteria. It may be noted, however, that for dried material, ozonation reduces the bacteria content. For wet materials, this cannot be confirmed due to the scattering of results; however, this does not mean an absence of an ozone disinfection effect (when analysing the results of the non-dried HF, ozone disinfection can be seen).
This means that the desired effect of ozone is observed with respect to both dry and wet materials (Table 1).

The light fraction contains much less mould fungi than the heavy fraction due to differences in morphology and differences in the types of raw material. Drying reduces the number of mould fungi by approx. 2-3 times-although this is not considered to be a large drop. Ozonation has little effect or no effect on the prevalence of mould fungi (Table 1).

In the case of the non-dried LF, the effect of ozone is ambiguous. In the case of non-dried HF, the number of microorganisms depends on the time of ozonation-the longer the better. With respect to the dried materials, results are clearly positive. Analysis of reference samples showed that the HF contains much more staphylococci than LF-this demonstrates the huge influence of morphology and type of raw material on the content and development of microorganisms (Table 1).

For wet samples, ozonation has a positive effect-this was more difficult to determine in the LF but was clearly visible in the HF, particularly after 45 min. Drying has a very significant effect in this case (Table 1).

With respect to the Salmonella spp., large differences in the reference samples were observed, making it difficult to draw unequivocal conclusions. As for the non-dried materials, only for the LF 'A' series was a decrease in the number of microorganisms observed, while for the ' $\mathrm{B}$ ' series, an increase was noted. This is due to the statistical nature of the examined variables. Similarly, for the dry fraction, a clear conclusion cannot be drawn as to the action of ozone, although a clear positive effect of drying was observed (Table 1).

In the case of the wet LF, the effect of ozone is positive. In the case of the wet HF, an increase in the number of E. faecalis was noted. With respect to the dried materials, results are not clear (Table 1). The interpretation of changes in the number of $E$. faecalis is difficult because the results are not conclusive. Nevertheless, it must be kept in mind that waste is a very specific material from a microbiological point of view. Waste, due to its composition, structure and abundance of nutrients, is a very friendly environment for microorganisms. Many of the isolated microorganisms can survive unfavourable conditions in a dormant stage, or produce different types of spores and capsules that protect them from harmful effects of temperature or ozone. Finally, attention should be paid to the fact that the process of drying the samples was carried out at $55^{\circ} \mathrm{C}$ for $48 \mathrm{~h}$. The temperature applied is therefore not so high as to effectively contribute to the elimination of all microorganisms.

In the case of $C$. perfringens, it cannot be concluded that the ozonation helps to reduce the number of microorganisms. For the light fraction drying effect is positive, but it does not occur in the case of the heavy fraction (Table 1). 
Based on the statistical analysis of the results, it was found that the differences in the number of microorganisms between the proposed variants of the ozonation process are statistically significant. The value of the $\mathrm{F}$ factor is as follows: 2139.13 for vegetative bacteria; 25.40 for spores, 5631.26 for mould fungi; 1743.95 for Staphylococcus spp.; 403.16 for E. coli; 2593.40 for Salmonella spp.; 629.02 for E. faecalis; 1097.50 for $C$. perfringens $(\mathrm{p}<0.05)$.

The ozonation process is currently used as an alternative to the use of UV radiation or toxic chemicals to remove bacteria, fungi and their spores, viruses, and protozoa [1-6]. In addition, ozonation causes destruction of mycotoxins produced by mould fungi [6]. Ozone was found to be lethal at the cellular level-oxidization of the fatty acids in the cell membrane and degradation of the nucleic acids (DNA and RNA) were both noted [4]. Due to these properties, ozone can be successfully applied to water, air, and a variety of surfaces. The effectiveness of ozone is dependent upon many factors, i.e. its concentration, exposure time, $\mathrm{pH}$, temperature and humidity [5].

Unfortunately, our research shows that in the case of municipal solid waste being the raw material for the production of refuse-derived fuel, ozonation did not bring such spectacular results. It should be remembered that the raw material for the production of alternative fuel is a mixture of many types of waste, including organic waste (green, kitchen, paper and cardboard, etc.), which are the perfect breeding ground for microorganisms. Waste matter often has a high level of humidity, a neutral $\mathrm{pH}$ and is rich in many nutrients necessary for the growth and development of pathogenic microorganisms.

In addition to the abovementioned characteristics, an irregular structure, a heterogeneous morphology and a high degree of porosity are certainly factors which facilitate the existence microorganisms on the surface of waste. Moreover, waste is colonised by mixed populations of microorganisms which are characterised by high biodiversity - in practice, this means that it is very difficult to effectively deactivate them [23].

\section{Conclusions}

When comparing the microbiological parameters of ozonized and dried light and heavy fractions of mixed municipal solid waste, it was found that the interpretation was sometimes ambiguous. Nonetheless, based on the collected data, it can be concluded that changes in the number of microorganisms colonizing the tested materials are influenced by the structure of these materials, which in terms of their morphology, are very diverse. Materials contained particles of varying size and porosity, they were able to absorb water and were variable with regard to their content of organic matter; therefore, they provided a source of nutrients for the microorganisms. The surface area of samples is also a determining factor in the effectiveness of ozone. It therefore seems reasonable to homogenise the particle size and thus the specific surface area prior to ozonation-this is easier to obtain for LF than for HF. The presence of water in some parts of the raw material (especially porous components) makes it very difficult to achieve ozonation, which is reflected in the results. This is due to the fact that $\mathrm{O}_{3}$ diffusion in gas is much faster than in liquid. The liquid may also function as a solution of constituents which can act as an ozone decomposition catalyst, preventing $\mathrm{O}_{3}$ contact with the microorganisms; therefore, it is advisable to remove the moisture and minimise porous surfaces prior to disinfection. In addition, studies concluded that different fractions of the raw material require different configurations of the ozonation process - this creates a necessity to double the processing line. Processing of the light fraction would take place in a stationary vertical reactor (vertical agitation can be provided by fluidisation) and processing of the heavy fraction would benefit from use of a horizontal, rotatable reactor with internal mixing elements to ensure proper contact between the reactants.

Acknowledgements The research and publication was covered by the GEKON Program and were part of the project entitled: EkoRDFinnovative production technology of alternative fuel from municipal solid waste for power plants - a key component of the waste management system in Poland: Contract No GEKON2/05/268002/17/2015. The project was co-financed by the National Centre for Research and Development and the National Fund for Environmental Protection and Water Management. The project leader is the EKOBIOMASA company.

\section{Compliance with Ethical Standards}

Conflict of interest The authors declare no potential conflicts of interest with respect to the research, authorship, and/or publication of this article.

Open Access This article is distributed under the terms of the Creative Commons Attribution 4.0 International License (http://creativecommons.org/licenses/by/4.0/), which permits unrestricted use, distribution, and reproduction in any medium, provided you give appropriate credit to the original author(s) and the source, provide a link to the Creative Commons license, and indicate if changes were made.

\section{References}

1. Kim, J.G., Yousef, A.E.: Inactivation kinetics of foodborne spoilage and pathogenic bacteria by ozone. J. Food Sci. (2000). doi:10.1111/j.1365-2621.2001.tb15218.x

2. Achen, M., Yousef, A.E.: Efficacy of ozone against Escherichia coli O157:H7 on apples. J. Food Sci. (2001). doi:10.1111/j.1365-2621.2001.tb15218.x 
3. Kowalski, W.J., Bahnfleth, W.P., Striebig, B.A., Whittam, T.S.: Demonstration of a hermetic airborne ozone disinfection system: Studies on E. coli. AIHA J. (2003). doi:10.1080/15428110308984811

4. Wysok, B., Uradziński, J., Gomołka-Pawlicka, M.: Ozone as an alternative disinfectant-a review. Pol. J. Food Nutr. Sci. 15(1), 3-8 (2006)

5. Habibi Najafi, M.B., Haddad Khodaparast, M.H.: Efficacy of ozone to reduce microbial populations in date fruits. Food Control (2009). doi:10.1016/j.foodcont.2008.01.010

6. James, R.R.: Potential of ozone as a fumigant to control pests in honey bee (Hymenoptera: Apidae) hives. J. Econ. Entomol. (2011). doi:10.1603/EC10385

7. Kim, J.G., Yousef, A.E., Dave, S.: Application of ozone for enhancing the microbiological safety and quality of foods: a review. J Food Protect. (1999). doi:10.4315/0362-028X-62.9.1071

8. Pascual, A., Liorca, I., Canut, A.: Use of ozone in food industries for reducing the environmental impact of cleaning and disinfection activities. Trends Food Sci. Technol. (2007). doi:10.1016/j. tifs.2006.10.006

9. Perez, A.G., Sanz, C., Rios, J.J., Olias, R., Olias, J. M.: Effect of ozone treatment on postharvest strawberry quality. J. Agric. Food Chem. (1999). doi:10.1021/jf9808291

10. Hwang, E., Cash, J.N., Zabik, M.J.: Postharvest treatments for the reduction of mancozeb in fresh apples. J. Agric. Food Chem. (2001). doi:10.1021/jf010234h

11. Mendez, F., Maier, D.E., Mason, L.J., Woloshuk, C.P.: Penetration of ozone into columns of stored grains and effects on chemical composition and processing performance. J. Stored Prod Res (2002). doi:10.1016/S0022-474X(02)00015-2

12. Coggiola, F., Porto, G., Rinaldi, G.: System and method for disinfection of refuse derived fuel, WO2007093281A1, WO Patent App. PCT/EP2007/000809, (2007)

13. Pearson, E.H.: Continuous treatment process and apparatus for the disinfection of infectious waste, US Patent 5116574 A, (1992)

14. Barberi, S., Jakobi, F.J., Bennettt, J.F., Webber, L.G., Barberi, L.J., Radonski, T.J., Englram, P.B., Kilham, K.: Hazardous waste sanitation and removal device, methods of use and applications thereof, Patent WO 2012094454 A2, (2012)

15. Kline, D., Meijer, R.S.: Multi-stage infectious waste treatment system, Patent application EP 0672426 A1, (1995)

16. Wichterle, K., Cieslar, J., Klečka, A., Klika, Z., Roubíček, V.: Fate of chlorine compound in combustion of alternative fuels. Acta Geodyn. Geomater. 3(1), 79 (2006)

17. Zhang, M., Buekens, A., Li, X.: Dioxins from biomass combustion: an overview. Waste Biomass Valoriz. (2017). doi:10.1007/ s12649-016-9744-5

18. Block, C., Caneghem, J.V., Brecht, A.V., Wauters, G., Vandecasteele, C.: Incineration of hazardous waste: a sustainable process? Waste Biomass Valoriz. (2015). doi:10.1007/s12649-014-9334-3

19. Panepinto, D., Tedesco, V., Brizio, E., Genon, G.: Environmental performances and energy efficiency for msw gasification treatment. Waste Biomass Valoriz. (2015). doi:10.1007/ s12649-014-9322-7

20. Caneghem, J.V., Block, C., Vandecasteele, C.: Destruction and formation of dioxin-like PCBs in dedicated full scale waste incinerators. Chemosphere (2014). doi:10.1016/j. chemosphere.2013.09.008

21. Edoa, M., Skoglundc, N., Gaoa, Q., Perssone, P.E., Janssona, S.: Fate of metals and emissions of organic pollutants from torrefaction of waste wood, MSW, and RDF. Waste Manag. (2017). doi:10.1016/j.wasman.2017.06.017

22. Adani, F., Baido, D., Calcatera, E., Genevini, P.: The influence of biomass temperature on biostabilization-biodrying of municipal solid waste. Bioresour. Technol. (2002). doi:10.1016/ S0960-8524(01)00231-0

23. Wolny-Koładka, K., Malinowski, M., Sikora, A., Szymonik, K., Pelczar, G., Wawrzyniak-Turek, K.: Effect of the intensive aerobic biostabilization phase on selected microbiological and physicochemical parameters of wastes. Infrastruct. Ecol. Rural Areas (2016). doi:10.14597/infraeco.2016.4.1.080

24. Aarab, T., Smeyers, M., Remy, M., Godden, B., Delhaye, J. P.: The storage of sewage sludge: influence of liming on the evolution of copper chemical fraction. Waste Manag. (2006). doi:10.1016/j. wasman.2005.10.007

25. Rodríguez, N.H., Granados, R.J., Blanco-Varela, M.T., Cortina, J.L., Martínez-Ramírez, S., Marsal, M., Guillem, M., Puig, J., Fos, C., Larrotcha, E., Flores, J.: Evaluation of a lime-mediated sewage sludge stabilisation process. Product characterisation and technological validation for its use in the cement industry. Waste Manag. (2012). doi:10.1016/j.wasman.2011.10.021

26. Healy, M.G., Fenton, O., Forrestal, P.J., Danaher, M., Brennan, R.B., Morrison, L.: Metal concentrations in lime stabilised, thermally dried and anaerobically digested sewage sludges. Waste Manag. (2016). doi:10.1016/j.wasman.2015.11.028

27. Gomez, E., Rani, D.A., Cheeseman, C.R., Deegan, D., Wise, M., Boccaccini, A.R.: Thermal plasma technology for the treatment of wastes: a critical review. J. Hazard. Mater. (2009). doi:10.1016/j. jhazmat.2008.04.017

28. Moisan, M., Barbeau, J., Crevier, M.C., Pelletier, J., Philip, N., Saoudi, B.: Plasma sterilization. Methods and mechanisms. Pure Appl. Chem. (2002). doi:10.1351/pac200274030349

29. Rimaitytè, I., Denafas, G., Martuzevicius, D., Kavaliauskas, A.: Energy and environmental indicators of municipal solid waste incineration: toward selection of an optimal waste management system. Pol. J. Environ. Stud. (2010)

30. Khairuddin, N., Manaf, L.A., Hassan, M.A., Halimoon, N., Karim, W.A.W.A.: Biogas harvesting from organic fraction of municipal solid waste as a renewable energy resource in Malaysia: a review. Pol. J. Environ. Stud. (2015). doi:10.15244/pjoes/34670

31. Lombardelli, G., Pirone, R., Ruggeri, B.: LCA Analysis of different MSW treatment approaches in the light of energy and sustainability perspectives. Chem. Eng. Trans. (2017). doi:10.3303/ CET1757079

32. Dong, J., Chi, Y., Tang, Y., Ni, M., Nzihou, A., Weiss-Hortala, E., Huang, Q.: Partitioning of heavy metals in municipal solid waste pyrolysis, gasification and incineration. Energy Fuels (2015). doi:10.1021/acs.energyfuels.5b01918

33. http://recykling.miki.krakow.pl/ripok/paliwo-alternatywne/. Accessed 26 August 2017, (in Polish) 